\title{
CONTESTATION OF RELIGIOUS IDENTITY IN THE CYBER WORLD: A CASE STUDY OF ARRAHMAH.COM AND VOA ISLAM DEALING WITH RELIGIOUS OTHERS ON FACEBOOK
}

\author{
AKMAL MUNDIRI* AND MOCH. TOHET \\ Universitas Nurul Jadid
}

\section{Abstract}

Religious identity frequently causes tensions that in turn lead to social polarization. Contestation and representation of religious identity not only hit the real world but also extend to virtual communities, which are part of a new form of identity contestation in the cyber era. This study uses an ethnographic approach focusing on the beliefs, language, values, rituals, customs, and behavior of people who interact in the community as the object of research. Thus, this study portrays the phenomenon of contestation of religious identity, both in the process of forming the identity (personal identity) of members or followers. The result of this study is that there is the process of forming religious identity on Facebook i.e., in the case of arrahmah.com and VOA Islam. Such process occurs because of the awareness of personal identity, in the form of aspects that differentiate others (self-categorization) and social identity in the form of religious identity that has been internalized through the interaction process in the group. While the demographic contestation of religious identity can be categorized into primary participators as creators of content and religious mindedness narratives, and secondary participators as members who are actively involved in consuming content, and lurkers as silent participants who are targeted by propaganda. The basic form of

\footnotetext{
* Corresponding author: Akmal Mundiri, Jl. PP Nurul Jadid, Dusun Tj. Lor, Paiton, Probolinggo, Indonesia, 67291. E-mail: akmalmundiri@gmail.com.
} 
contestation in these two communities is exclusive religious understanding and views other groups as 'the other'.

Identitas agama seringkali berpotensi menimbulkan ketegangan-ketegangan yang dapat melahirkan polarisasi sosial. Kontestasi dan representasi identitas agama ini bukan hanya terjadi di dunia nyata, akan tetapi juga merambah pada komunitas virtual, yang secara keseluruban merupakan bagian dari bentuk baru dari kontestasi identitas di era siber. Penelitian ini menggunakan pendekatan etnografi, yang memusatkan perhatian pada keyakinan, bahasa, nilai-nilai, ritual, adat istiadat, dan tingkah laku orang yang berinterksi dalam komunitas yang menjadi obyek penelitian. Dengan demikian, penelitian ini memotret fenomena tentang kontestasi identitas agama, baik dalam proses pembentukan identitas atau identitas personal para follower. Hasil penelitian ini menunjukkan bahwa proses pembentukan identitas agama di Facebook, baik group Facebook arrahmah.com ataupun VOA Islam terjadi karena adanya kesadaran akan identitas personal, yang berupa seperangkat aspek, yang membedakan dengan orang lain (kategorisasi diri) serta identitas sosial yang berupa identitas agama yang telah terinternalisasi melalui proses interaksi di group. Sedangkan demografi kontestasi identitas ini dapat dikategorikan menjadi tiga: primary participators sebagai pembuat konten dan narasi religious mindedness; secondary participators sebagai anggota yang terlibat aktif mengkonsumsi konten; dan lurkers sebagai partisipan pasif yang menjadi target propaganda. Bentuk kontestasi mendasar yang terjadi dalam kedua komunitas tersebut adalah tentang paham keagamaan yang eksklusif dan memandang kelompok lain sebagai 'the other'.

Keywords: cyber world; religious community; religious identity; social media; virtual contestation.

\section{Introduction}

The dynamics of cyber society today also do not escape personal identities and groups that are characterized by religious narratives that tend to be salafi manhaji or moderate. This dy- 
namic certainly departs from the accessibility of cyber media which makes it easy for users of all ages, religions, views, and identities to access, provide views, and so on. With this convenience, cyber media is like a coal in the chaff or the trigger of conflict that can be withdrawn at any time. Including integration between groups in the cyber community as a consequence of the interaction of a borderless world can lead either to integration or conflict seen as two things twisted with each other like bracelets rubber tightening and relaxing every time. Conflicts with such community on any behalf can be withdrawn any time without doing direct propaganda. In addition, ease of accessibility on such matter requires an impact that is quite crucial for the mushrooming of radicalism and transnational Islamic movements.

Radicalism and transnational Islamic movements can be likened to finding a new hope in "marketing" their products in the form of virtual contestation. The virtual contestation allows this movement to carry out shot and run propaganda or even borrow other users' hands to hit other groups' thoughts. The contestation that began in the offline world and was clearly seen increasingly finding momentum in the virtual era because of issues and anything more easy to disseminate. Thus, the cyber era with its easy access has a large role in the process of disseminating information, communication, and propaganda of extreme religious-mindedness (Berger and Morgan 2015).

Thus, clash of arguments as happened in a cyberspace also necessitates the existence of religious conflict. In the cyberspace, each member shows and emphasizes their religious identities rather than shared identity or bhinneka tunggal ika. Identity representation that arises because of a different sense of trust, in a virtual community also raises the seeds of horizontal conflict among members of a community. In the cyber community, integration and conflict are closely related. 
The identity representation that starts from the contestation and ends in the clash of arguments is attached to each group to become a group identifier so that the nicknames that arouse one another emerge. The availability of the original public space is expected to bridge mutual understanding among others or at least two sides of group without highlighting identity in the end and to further strengthening the issue of contestation and representation of religious identity in the public space. This identity is then an important part of self-concept. Self-concept includes what is thought and what is felt about yourself. The self-concept is also defined as what you think and feel about you, the entire complexity of beliefs and behaviors you hold about yourself. All individual thoughts and feelings in reference to oneself as objects form their self-concepts. Thus, identity becomes a part of the self that is known by others (Sarlito 2005).

Thus, the issue of identity which ends in clash of arguments becomes embers in chaff in virtual communities on social media, particularly in Facebook. Contestation occurring due to the lack of agreement on religious views is an interaction. Thus, in a virtual community on Facebook, there are certain issues which entail two potential sides, i.e., contestation, and acceptance. These sides or dimensions are shown in a variety of ways by community members so that they sometimes cause clash of arguments. The contestation of religious identity in some virtual communities is usually indicated by the theme of relations between religion, nationality, and nationalism (Berger and Morgan 2015).

Research that examines identity is indeed quite a lot but generally tends to be directed at the lives of people who are classified as traditional, such as research on Dayak, Sawu (Rote), Samin, Osing, Tongan and etc. The discussion in research that examines the traditions of traditional communities is only concerned with cultural politics in each ethnic group (Sukamto 2010). Research 
on identity have been carried out quite frequently and has become the theme of cultural studies in the 1990s. Identity is best understood not as a fixed entity, but as a picture of the subject of self-fulfillment with emotional content. It is images of self that reflect essential identities (Valentine 1998). Identity makes a picture of a person, through physical appearance, racial characteristics, skin color, practical language, self-assessment, and other perception factors, all of which are used to construct cultural identity. Identity is important within cultural communication. The concept of identity can also be seen from the aspect of culture as well as emotional significance, which makes someone attached to something, which distinguishes it from other people so that it is easier to recognize. The purpose of this identity is to make and build communication (A'yun 2015).

The discussion about identity has yet touched other lines such as the identity of urban communities or other social institutions. The fact that such cases exist explains that the identity of urban communities or other social institutions tends to be more complex and has more combinations so that the political identity of the community have not been found. Therefore, studies of identity are not considered relevant if only relying on the theories of a group of experts. In this case, the discussion about identity that focuses on the interaction of religious identity actor as well as the actor's direct experiences within the naturalistic research methodology is called tacit knowledge.

Thus, it is appropriate to not only use a constructionist approach but also employ constructional methodology, phenomenology or an effective methodology. Identity representation in its working system works through a representation system consisting of two components, namely the concepts of the mind and of the language used. These two components are interrelated. The concepts within the mind will not become any meaning without 
being communicated with the medium of language. In identity representation, there is a totalism and the mutually symbiotic character between variations in the type of identity of the subject and the character dynamics of the structure. Consequently, sometimes there is conflict and consensus in the development of the subject's identity and there is even world-afterlife attraction in its religious concept (Mappiare 2005).

Religiosity is one of the cultural identities inherent in both the person and the community group. Religiosity according to Koentjaraningrat (1987) is part of culture. Koentjaraningrat's statement confirms what was revealed by Emile Durkheim who stated that religion as part of culture is based on the component of religious emotion, a belief system that encloses human beliefs about the nature of God, religious ceremonial systems, and religious groups that link the belief system (Baharun and Mundiri 2001). In practice, the manifestation of religious expression can also be referred to as a religious expression or religious experience. According to Smith as revealed by Romdhon, religion consists of several forms which are part of religious elements. These elements are teachings, symbols, practices, and institutions. These elements are manifested in the form of speech-language, symbols, and meanings of status in a virtual group (Romdon 1996). Similarly, aspects of religiosity can be understood from doctrine, mythology, ethics, rituals, social institutions and religious experiences (Capps 1995).

Identity in the context of the cyber world can be interpreted as a collective solidarity of a group (Klinken and Nordholt 2007). The fact indicates that someone who is in a community will tend to abandon his personal identity to be replaced with his group's identity. The personal identity of community members can be examined from a sociological and psychological approach. Therefore, to find out the relationship between identity 
and action, it can be further clarified by using the concept of framing as part of a psychological approach (cognition). In this case, framing becomes a mechanism of meaning in a collective identity of contemporary events (Klinken and Nordholt 2007).

Nowadays, the issue of identity manifested in the form of religious identity becomes a trending topic of talk in its numerous forms, the impact of which is also unimaginable. Identity in this dimension has penetrated almost all lines of human life so far as it relates to human identity (self). In this case, the evidence of religious identity has almost breached almost all aspects, one of which can be identified by religious identity which is increasingly demonstrative, even displays its own identity, and at some point creates tensions that lead to social polarization (Sukamto 2010).

This research is limited only to Facebook as the most favorite social media for various circles, races, religions, and ages. This media is one of the media other than Twitter, and Instagram which has a considerable role in providing information and influencing one's awareness and insight (The Policy Institute 2018). In this dimension, Facebook becomes one of the propaganda media which certainly cannot be separated from understanding the identity of their respective groups. The ease and accessibility of Facebook makes several groups with different identities able to preach and to internalize their identities. This space then becomes a battle space among different groups fighting for the power of the identity of their followers and enables the hybridization of identity in the form of cross affiliation and identity based on dynamics and social interaction.

Hence, to understand this existing condition, this research is only specified to Islamic narratives that thrive on Facebook groups i.e., VOA Islam and arrahmah.com. VOA Islam and arrahmah.com based on the results of research conducted by Con- 
vey Indonesia, including two of the many virtual communities that support radicalism (PSBPS Universitas Muhammadiyah Surakarta 2018). This research is an ethnographic type by making the virtual Facebook arena as the locus for shooting the phenomenon of religious identity contestation. Therefore, this type of research can be regarded as virtual ethnography that seeks to portray phenomena in society and the culture of netizens in cyberspace (Nasrullah 2014). Thus, the data in this virtual ethnographic study are in the form of words, behavior, documents, and others related to the personal identities of members of the VOA Islam and arrahmah.com. To obtain data in a holistic and integrative way and to make them relevant with the focus and purpose of the research, the researcher used observation collection techniques, in-depth interviews, and documentation. The data analysis technique used is the Spradley data analysis model, which is adjusted to the research stage.

\section{Social Media: A New Patterns of Communication and Interaction between Identity}

Social media removes humans boundaries in their interactions. Apparently, limitation of time and space has no effect. Social media allows people to communicate with each other wherever and whenever they are, without worrying about distance them and being affected by time (day or night). Social media has a big impact on our lives today. Someone who is originally "unknown" can immediately become famous with social media, and "great" people can instantly become "worthless" by the power of social media. Social media is a group of internet-based applications built on ideology and Web 2.0 technology and allows the creation and exchange of user-generated content (Musthofa 2016). Globalization changes people's way of thinking and behavior to be more modern. Each individual begins to celebrate the freedom of expression and interact with his own style. Per- 
sonal affairs turn out to be public consumption, not to mention the administrative realm of the government system that is likely to become a heated debate through mass media and social media (Kusumaningrum, Hardyanti, and Pradana 2017).

The interaction of communication that goes along naturally with the basis of this mutual need in its development has turned into an interdependent interaction. In this dependency theory, the public or audience becomes "confined" by the presentation of information from the media. This theory of dependence on media was originally initiated by Sandra Ball-Rokeach and Melvin Defleur. The theory departs from the nature of modern society, in which mass media is considered as an information system that has an important role in the process of nurturing, changing, and conflicting at the level of society, groups, and individuals in social activities.

Shortly speaking, the study of these effects can be formulated as follows; first, cognitive effects are the consequences that arise in the communicant who is informative for him. With mass media, someone gets informed about objects, people or places that they have never seen or visited directly. Second, Affection, this effect is higher than the cognitive effect. The purpose of mass communication is not just to inform the audience about something, but more than that, the audience is expected to be able to participate or feel emotionally involved. After hearing or reading the news, a feeling of resentment, annoyance, anger or pleasure in the audience arises. Third, Behavioral, this effect is a result that arises in the audience in the form of behavior, actions or activities. Violent scenes on television or film can influence people to become violent (Irianti 2017).

This dependency theory is similar to the uses and needs fulfillment theory. The only difference spots on the active audiences' perspectives. The theory underlines $t$ that audiences do not 
have the same dependence on all media. This model shows that media systems and social institutions are interconnected with audiences in creating needs and interests. Thenceforth, the idea of authentic culture formed outside the media is something flexible, but misguided because of differences in the youth subculture. In many cases, it is a media phenomenon. The media is claimed to be an integral part of subculture formation and the formulation of young people for their activities (Barker 2005).

To recognize identity on social media there are several patterns that can be used, namely; first, Allocution, is a communication pattern where information is disseminated from one center to several points shared simultaneously. Concurrently, such information is also spread to all followers. Second, conversation, this communication pattern allows everyone to interact through either being mediated or direct way.

The main key to this conversation is that there is equality between the parties involved in the interaction. For example, it is an e-mail in which conversation is mediated by a third party in the form of electronic mailing. Third, consultation, this is a communication pattern in which between the parties involved have functions as a bank of information that can be used as a place to find information needed. A printed newspaper is one of the media that uses a pattern of consultation communication, in which there is a wide variety of information. Fourth, Registration: The pattern of registration communication is the opposite of the consultation pattern, where the center requests and receives information from participants in the periphery (Karman 2014).

Social media is said to be a cultural transformation, especially in social interaction. How we see in the present that identities, relationships, and communities can be formed through social media, how we live and work are very dependent on technology. How the internet has changed the way we live. That we can shop 
online, connect with family and friends, and get acquainted with new people, make us difficult to distinguish between social media users in the category of independence and dependence. The following is an overview of social media seen from the approach of social interaction and integration in the field of Communication Science. The social interaction approach distinguishes the media based on how close the media is to the face-to-face model. While through the integration approach, social media is described not in the form of information, interaction or dissemination but in the form of rituals. From the point of view of social interaction, social media creates a new understanding of interactive personal communication. Social media is not as same as a direct interaction (face to face), but provides a new form of interaction that brings its users back to interpersonal relationships, namely in the form of mediated interactions or called Computer Mediated Communication (CMC). Through social media, individuals can interact with each other in real time.

\section{The Process of Forming Religious Identity in Facebook Religious Communities}

The current period of globalization is full of all forms of modernization, human life goes indirectly and occurs in two worlds; real and virtual worlds. The emergence of technology that increasingly facilitates human life is a sign of the modernization that is able to divide social reality into two worlds; the real world and cyberspace. Technological sophistication makes social interactions "evaporate in the air". Almost all human activities are currently carried out in cyberspace, in terms of social activities, politics, economics, culture, law, education, health, entertainment, and others. Communication intertwined between one person and another is no longer merely through face-to-face method but melts in cyberspace. 
The personal self-concept of group members of a community is not only formed by its social identity, but also by its personal identity. This is caused by social relations which are basically a continuum that ranges from personal to social relationships. In this study, it can be categorized that the personal identity of members of the religious community, in this case, VOA Islam and arrahmah.com members, consists of a set of aspects inherent in the members that distinguish them from others. The current context requires that Facebook as the most quite loved social media in the cyber era, which among similar platforms also offers space for mediation and inter-subject interaction in the virtual space. Facebook, founded by Mark Zuckerberg, provides an application that can build communication between subjects without limits of space and time. In this application, the user is provided with space to write profiles and status that can be accounted for or even cannot be justified. With this convenience, Facebook users can create and even construct their image without intervening in the text contained in the profile or status, as well as a collection of images of the Facebook account owner. Creation of identity spaces on Facebook can be opt-in (can only be read by the account owner, some friends on the Facebook network, or friends from friends on the Facebook network) or opt-out (which anyone can read).

The process of forming religious identity among religious communities on social media such as Facebook is due to the operation of self-categorization, social comparison, and interactivity. The self-categorization process which according to Cameron is in the form of awareness of membership in groups that can be used to distinguish individual from another individual from a different group, to not heed a positive self-image (see Afif 2015). This difference becomes one of the differences between the offline and virtual world. The advantage of the virtual world 
is able to distinguish identities that actually makes individuals in them no longer think of positive images or material profit and loss in choosing which category of identity to follow. So, in each of these communities, each individual will survive with his choice based on his life experience and interactions in the real world. Self-categorization in the formation of religious identities in two communities is determined by the strength or absence of personal identity in the real world. Thus, the phenomenon that took place in the two Facebook groups in the formation of religious identity has led to the assumption of a weakening of social identity and strengthening of personal religious identity.

The process of self-categorization in both groups, both the arrahmah.com community and VOA Islam perceives mutual similarities between individuals in the community, although frequently assumed that intruders with different views with them appear. It was the process that internalizes religious identity between individual and another who shares similar views and makes that identity a shared viewpoint that should be protected from other views that do not represent the group's shared viewpoint. The views that arise outside the view of group identity will strengthen the depersonalization process and grow into a kind of consensus and able to erode perceptual tackle among group members.

The VOA Islam and arrahmah.com are the two communities considered to be one of the sites involved in the network of religious intolerance and radicalism discourse in Indonesia. They often ignore journalistic ethics as agreed by the cyber media journalists association (PSBPS Universitas Muhammadiyah Surakarta 2018). Furthermore, in order to raise their website ratings, it is not uncommon for them to be regarded as against the code of ethics by spreading hoax news. Both of these communities also have followers who are quite fanatical who sup- 
port religious truth claims. In each of these communities, there is a prominent view of the superiority or perceived superiority of the group itself. In both communities, group members accentuate themselves in the form of religious attributes when dealing with status updates on personal or community walls of Facebook. Status updates pertain to religious views that are taken into account correct so that they think that those other than them have wrong understanding.

Based on the description, it can be concluded that self- categorization in the formation of religious identity in the cyber world is determined by the strength of personal identity in the real world. Therefore, it is likely to hold that such phenomenon in the cyber world raises the assumption of weakening social identity and of strengthening personal religious identity. The personal identities of each member of the two communities can be seen from the background perceived in the profile of the Facebook members of each community. In the Facebook profile of each community, personal background does not designate linearly with self-identity in the cyber world. In this study, personal identity in that category is seen in the form of specific personal beliefs, personal desires and goals, and moral principles. However, the fundamental problem about the contestation of religious identity represented in the Facebook virtual community is the problematic religiosity and religious-mindedness.

The results also show that the behavior and intelligence of both arrahmah.com and VOA Islam members are rigid and tricky. They appreciate their own community and underestimate other group members. Since then, they severely attack each other in the cyber war by addressing what-so-called their "enemy" with bad names i.e., cebongers (from the word kecebong which means an infant frog) and kampret (which means a bat) The term cebongers is addressed for groups that tend to be moderate 
in looking at diversity and kampret for groups that are considered rigid in coping with diversity. Such names are political and are nothing to with religiosity. This behavior is in line with the theory of self-categorization, namely stereotyping, where an individual in a community is prone to perceive their own group as the best and consider other groups as the worst (Afif 2015).

The behavior of self-categorization in the formation of religious identity in this study is shown by high fanaticism towards the group (ingroup favoritism) and its members have high self-esteem compared to individuals with different views with him. However, this high level of self-esteem towards religious views seems to only infect members of the arrahmah.com and VOA Islam communities who indeed view religious teachings as something taken for granted and individuals who differ in their views as kafir. The process of forming a religious identity that leads to self-esteem according to Afif is formed cognitively from the process of self-stereotyping and metacontrast.

The process of forming religious identity in the cyber world also comes to pass due to positive or negative judgments by individuals of different religious understandings. This is in line with what was revealed by Afif that too strong self-categorization would lead to and trigger the birth of aggression and insult to other groups (Afif 2015). This difference is increasingly exaggerated based on the observations of researchers. In the end, it will make the status rating go higher because of many comments attacking each other.

Both of these communities also frequently update and post statuses on anything that favor their group and downgrade religious understanding narratives which do not conform with their standpoints. Both community members arrahmah.com and VOA Islam compare themselves with other members regarding their similarities and differences, in order to get positive aspects 
of their own views. The positive aspects that help build their religious identities are ironically motivated by insulting others and rejecting diversity among others. Furthermore, the motives on feeling the most superior, looking down others, and raising ratings become part of their habits. Comparison of religious understandings also necessitates the benefits of achieving group identity that is increasingly different from the others covered in the theory of optimal distinctiveness (Afif 2015). Sources of references for community members who have similar views with the arrahmah.com and VOA Islam community stem from online literacy which for now has begun to shift the role of religion in the authorization of religious views.

Thus, the process of forming religious identity in both communities is not only determined by group behaviors in terms of derogating others, but also by individuals in a community in interacting with other group members as shown in figure 1.

Figure 1

The construction of religious identity

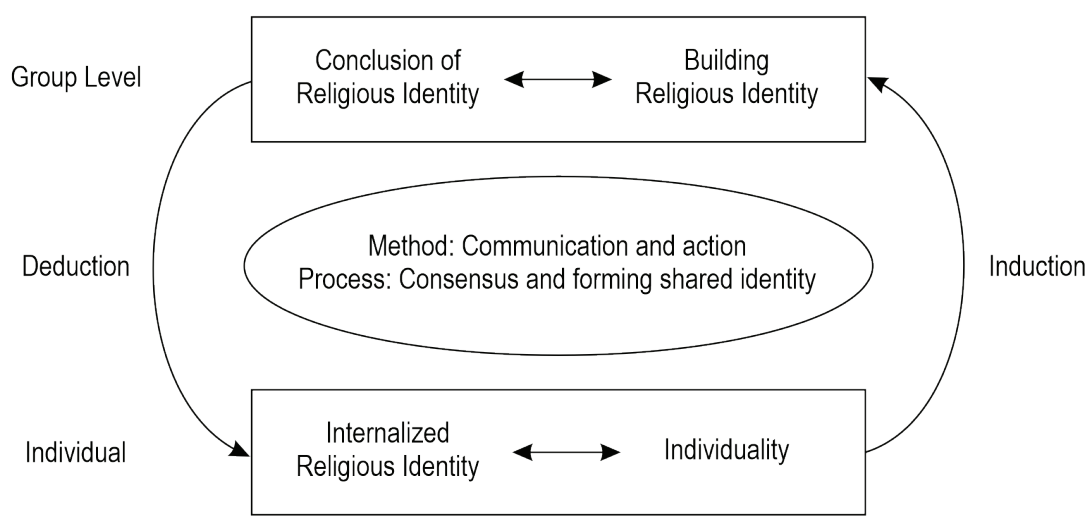

The process of forming religious identity based on the figure 1 is formed by group factors and individual factors. The process passed in the formation of religious identity occurs through a process of communication and action between individuals in a 
virtual community. The process ultimately requires the formation of a shared identity. If there is no understanding of religious identity between individuals in a group, it seems impossible to form a religious community. For that reason, it can be said that the process of forming the religious identity of religious communities on Facebook is an interrelated formation process between person-based religious identities, relational religious identities, and group-based religious identities.

\section{The Contestation of Religious Identity: Social Media,} Community, and Identity in Cyber Era

In order to build moderate society, Indonesia responds such issue positively through campaigning Islamic values by demarcating Indonesian ideology with radicalism and extremism. The campaign is part and parcel among Indonesian efforts to clarify misunderstanding of westerners. The westerners often claim that the most populated Muslim countries vulnerably undergo the failure of democracy consolidation (Huntington 1993). However, this phenomenon has coped with other opinions due to the diversity of Indonesian people's religious views. There are religious groups that tend to be moderate and to be strictly religious-minded. The lattertends to be rigid and phobic in dealing with differences within their religious views. It should be noticed that the different views do not only happen in the real world, but also in the cyber world with the emergence of virtual sites and of intolerant communities. They seem to be radical as revealed by Zaenuddin who maintains that those who are in dispute in cyberspace are scattered and simultaneously the would fight, both in the form of sites and virtual communities that get Islam colored with different styles (Zaenuddin 2018).

In this way, the cyber era has become a challenge in defending and promoting the face of friendly Islam. The issue of religious identity with the mindset of truth claim of individual becomes 
a separate problem in preserving Islam as the religion of mercy upon universe (rahmat li al-'álamin). On the one hand, the identity of a group can help encourage its members to cement solidarity and solidity for making them more organized. This is, of course, a little worrying based on the finding of Martijn van Beek which describes that identity which is more specifically religious identity is one of the biggest contributors to conflict (Beek 2000). This is in conformity with the opinion of Immanuel Wallerstein who states that 'we are living in an era of groupism' (Wallerstein 1995). There is no individual who can live with himself/herself (individuality). Someone must be grouped and form a communal identity. So, it is seen that identity is able to build a strong bond of solidarity and create an effort to defend group members or groups though producing oppositions among different groups (Soenarno 2002).

Nowadays, these groups are not only evident in the real world but also have penetrated into cyber space indeed. The existence of these groups in cyber media also requires the contestation of views and efforts to maintain their identity stronger than the real world. It is influenced by several reasons including cyber media or Facebook which is the locus of discussion in this study. Such media give them virtual advantage since it can hide the profile of group members so that they feel free to do so. It is in agreement with Raharjo's point of view that "people in virtual communities do just about everything people do in real life, but we leave our bodies behind" so the use of pseudonyms in his view to hiding personal identity is something usual in cyberspace (Raharjo 2002).

The form of religious identity contestation in both virtual communities arrahmah.com and VOA Islam also makes religious narratives tend to be intolerant and radical. The two in turn become controversial communities which ultimately can 
raise the rating of their news sites. The issue of conflict about religious ideas which then enters into the realm of politicization of religion becomes a remarkable issue. It has a direct impact on the ongoing media as the main media of the community. In the VOA Islam and arrahmah.com community, the demographics of Facebook users can be divided into three groups, namely the first group is the primary participators, as the creator of content and information that exists in cyberspace and social media. There are secondary participators who usually consume information and are actively involved in the interaction and representation of identities of both groups and individuals in the community. The third group is lurkers who only consume information. The number of this third group can exceed the two others. The third group in the VOA Islam and arrahmah.com community only gives occasional responses with "likes" as a virtual proof that the status or posting of content corresponds to what is also their hope without giving any responses or arguments. While the second group tends to be actively involved both in the form of interactive comments and posting status on the community Facebook wall. However, the issue of identity raised by status or comments of this type varies which represents diverse identities. This was marked by a variety of conflicting comments in understanding religiosity. This behavior indicates that community members who become community followers do not only aim to monitor their status or combine themselves in the same identity, but to justify "theyness" and "otherness."

Hence based on the aforementioned elaboration, one of the expectations of the primary participators is to raise their community ratings so that the rating of the Islamic news sites they manage will be increased even though it will indirectly foster enmity and hostility among other groups. One of the expectations of the primary participators is to raise community or group rat- 
ings. It is accordingly advantageous for increasing their Islamic news sites as the opponents of other religious groups. This problem is based on the interview of researchers with one of the informants who stated that this religious identity is a pledge in achieving goals because it is difficult to put together. Religious identity is as same as identity which is built by ideological principles rather than by temporary and artificial interests (Afif 2015). Religious identity that comes from the process of interaction or what is understood by members of the VOA Islam and arrahmah.com is inversely proportional to what was held by Marzuki that:

"The high religious awareness influences the actualization of one's soul in daily life manifested in the form of psychiatric and spiritual activities such as mutual help, helping others, respecting others, and internalizing universal values.” (Marzuki 1997).

Religious identity is a manifestation of religious values that grow and develop in the aspects of individual or group life with its distinctive characteristics among others. Religious identity and popular culture represented by social media influence each other because both meet repeatedly in the same medium and spatial space. Religious practices are presented in the form of a mixture of text, discourse, and symbolic materiality from popular culture and nation-state. The context of the post-authoritarian society in Indonesia and authority fragmentation in circulating discourse and commodities has opened up space for traditions of thought, historical interpretations, and dimensions of religious beliefs that are used to understand individuals, objects, texts, and foreign modes of circulation. There are restrictions and acceptance of these things in a logic that departs from a long history and relational relationships with each other. In this context, Islamic identity and popular culture are anchors that 
explain that Islamic piety and various popular cultural material influence each other in an event (Ardhianto 2016). Religious identity is born from the characteristics of community members consisting of several layers of life with their religious activities. In the process of interaction, culture is created which transforms to te their identity i.e., a religious identity.

In the context of identity in the cyber world, which in this case is the VOA Islam community and arrahmah.com, the meaning of religiosity shifts with a narrow religious identity. In order to maintain the argument of religious understanding towards other groups, it is ordinary for individuals in these communities to use insults addressed to others whereas such insults are of no value in any religion and considered evil and sinful. Furthermore, the communities, driven by their hatred and anger, sometimes call "the others" though they are Muslims as infidels. This issue provokes the members to the religious truth claim asserting that their religiosity is the most perfect and most pleased by Allah. There is no other salvation can be achieved unless through these groups. This religious truth claim shifts to become their identity to propagate their faith and to declare determination of their followers. Their different perspectives in understanding the truth of religion lead them to be exclusive for they assume that their religious identity is the most correct and valid while others are wrong and invalid.

The contestation of religious identity that takes place in the cyber world can eventually give birth to conflicts and violence against other religious groups and minority beliefs. This certainly contradicts the spirit built by religion itself since theoretically, each religion by its adherents is believed to teach tolerance, respect, and recognition of the existence of other religions and beliefs. In this context, Islam (as well as other religions) has affirmed such teachings as stated by the Quran "lakum dinukum 
wa liya din" . In fact, Islam also teaches tolerance and respect for furu'iyyah part (different views on doing worship) in the Muslim internal circle with the principle of "lana a'mālunā wa lakum a'mālukum" (for us to be our guardian and for you, your faithfulness). Practically, this principle has not been fully realized by Indonesian people who are noticeably multi-religious and trustworthy. They are still reluctant to accept diversity totally. The tendency of homogeneity in the true sense is still apparent. There are still many difficulties in doing dialogues between existing groups. Supposedly, the dialogue is still ceremonial and formalistic which has yet touched the core problem faced (Tajrid 2012).

The stereotyping of arrahmah.com and VOA Islam communities requires to have a "sense of communality" that will maintain the commitments made. Feelings of members who belong to each other have mutual interests between members and groups, and the belief that members' needs will be fulfilled through mutual commitment. Thus, the members or followers of the arrahmah.com and VOA Islam communities will share photos, pictures, information and so on by mentioning each other, tagging to accounts allying with them. Other behaviors that are also carried out community members are also in the form of spam on various information or things that can cause various forms of insults to other groups. The members of the VOA Islam and arrahmah.com share spam and war of identity as a form of protection against other groups attacks of preservation of their 'truth'. Thus, verbal violence is manifested in the form of texts, status, wall comments made with crude expressions about invective or satire that escort to the topic being discussed. Volunteering all the weaknesses and mistakes of each identity in the form of written words or memes becomes a thing that often triggers the cyber war on the religious identity. 


\section{Conclusion}

To sum up, two important findings can be identified; first, the process of forming the religious identity of the religious community on Facebook, both in the arrahmah.com and VOA Islam communities, arises in the form of a social identity or personal identity. The process begins with an awareness of each member in a group, so that it can be used to distinguish one from another, in different groups, to not heed a positive self-image. The technique used in the formation of religious identity occurs through a process of communication and action between individuals in a virtual community which ends in a shared identity formation process.

Secondly, the contestation of the religious identity of the religious community on Facebook, in addition to aiming to raise the rating of their main website, aims to spread rigid religious-mindedness in interpreting religious texts and leading to the formation of communal identity. This identity bond will ultimately create a strong bond of solidarity that is ready to defend their interests. The two communities peddle intolerant and radical religious narratives as sale in perceiving identity. Also, these two communities have three categories of users; primary participators, secondary participators, and lurkers. The basic form of contestation that appears in these two communities is exclusive religious understanding. It implies others as "the other" and leads to truth claims. This viewpoint is part and parcel supported by popular social media activities such as sharing photos, images, information, etc. The identity is then bolded by the features in Facebook through mentioning each other. For instance, it can be done by tagging accounts with one identity, spam and buzz on various information or things that can steer to various forms of insults delivered to other groups, and spams of identity as a form of protection against the existence of their religious understanding of the group invasion in various forms. 


\section{Bibliography}

A'yun, P. Q. 2015. "Fenomena Remaja Menggunakan Media Sosial dalam Membentuk Identitas." Jurnal Channel, 1-15.

Afif, Afthonul. 2015. Teori Identitas Sosial. Yogyakarta: UII Press.

Ardhianto, Imam. 2016. "Kontra Publik Keagamaan dalam Media Baru: Islam, Kebudayaan Populer, dan Media Sosial pada Gerakan \#IndonesiaTanpaJIL." Jurnal Antropologi Indonesia 37 (2). doi:https://doi.org/10.7454/ ai.v37i2.8768.

Baharun, Hasan, and Akmal Mundiri. 2001. Metodologi Studi Islam; Percikan Pemikiran Tokoh dalam Membumikan Agama. Yogyakarta: Arruzz Media.

Barker, C. 2005. Cultural Studies; Teori dan Praktek. Yogyakarta: Kreasi Wacana.

Beek, Martijn van. 2000. "Beyond Identity Fetishism: Communal Conflict in Ladakh and the Limits of Autonomy." Cultural Anthropology 15 (4): 525-69. doi:10.2307/656621.

Berger, J.M., and Jonathon Morgan. 2015. The ISIS Twitter Census: Defining and Describing the Population of ISIS Supporters on Twitter. Analysis Paper: The Brookinngs Project on U.S. Relations with the Islamic World. Brookings: Center for Middle East Policy The Brookings Intitute.

Capps, Walter H. 1995. Religious Studies: The Making of a Discipline. Minneapolis: Fortress Press.

Huntington, Samuel P. 1993. The Clash of Civilization and Remarking of World Order. New York: Simon \& Schuster.

Irianti, Een. 2017. "Dampak Ketergantungan Media Sosial pada Kalangan Dystopian dan Utopian.” Communicatus: Jurnal Ilmu Komunikasi 1 (1): 67-78.

Karman. 2014. "Media Sosial: Antara Kebebasan dan Eksploitasi Sosial Media." Jurnal Studi Komunikasi dan Media 18 (1): 75 . 
Klinken, Gerry Van, and Henk Schulte Nordholt. 2007. Politik Lokal di Indonesia. Jakarta: Yayasan Obor Indonesia.

Koentjaraningrat. 1987. Sejarah Teori Antropologi. Jakarta: Penerbit Universitas Indonesia.

Kusumaningrum, Demeiati Nur, Winda Hardyanti, and Hafid Adim Pradana. 2017. "Komunitas Digital AIMI dan Gerakan Sosial Berbasis Facebook." Jurnal Islamic World and Politics 1 (1): 72.

Mappiare, A. 2005. “Identitas Religius Perempuan Islam: Kajian dalam Perspektif Teori Kritik Ercih Fromm atas Pemakaian 'Jilbab Modis' Oleh Mahasiswi di Kampus Muhammadiyah Malang." Universitas Airlangga.

Marzuki. 1997. "Pendidikan Agama Islam di Perguruan Tinggi Umum dan Pemberdayaan Masyarakat Indonesia." Cakrawala Pendidikan XVI (1).

Musthofa. 2016. "Prinsip Dakwah Via Media Sosial.” Jurnal Aplikasia 16 (1): 51-55.

Nasrullah, Rulli. 2014. Teori dan Riset Media Siber (Cybermedia). Jakarta: Kencana.

PSBPS Universitas Muhammadiyah Surakarta. 2018. "Radikalisme di Website dan Media Sosial.” In Ringkasan Eksekutif Program Convey Indonesia, edited by Convey Indonesia. Ciputat: PPIM UIN Jakarta.

Raharjo, A. 2002. Cybercrime: Pemahaman dan Upaya Pencegahan Kejahatan Berteknologi. Bandung: Citra Aditya Bakti.

Romdon. 1996. Metodologi Ilmu Perbandingan Agama. Jakarta: Raja Grafindo Persada.

Sarlito, S. 2005. Psikologi Sosial. Jakarta: Balai Pustaka.

Soenarno. 2002. Kekuatan Komunitas sebagai Pilar Pembangunan Nasional. Jakarta: Gramedia Pustaka. 
Sukamto, G. 2010. "Politik Identitas (Suatu Kajian Awal dalam Kerangka dan Interaksi 'Lokalitas' dan "Globalisasi).” Jurnal Sejarah dan Budaya 2 (2): 9-23.

Tajrid, Amir. 2012. "Kebenaran Hegemonik Agama.” Walisongo: Jurnal Penelitian Sosial Keagamaan 20 (1): 193-210.

The Policy Institute. 2018. "Respon Pembaca terhadap Publikasi Buletin Muslim Muda Indonesia." In Ringkasan Eksekutif Program Convey Indonesia, 87-90. Ciputat: PPIM UIN Jakarta.

Valentine, James. 1998. "Naming the Other: Power, Politeness and the Inflation of Euphemisms." Sociological Research Online 3 (4): 1-17. doi:10.5153/sro.184.

Wallerstein, Immanuel. 1995. The Modern World System III: The Second Era of Capitalist Great Expansion. London: Academic Press.

Zaenuddin, Ahmad. 2018. "Kompetisi di Antara Situsweb Islam.” Tirto. https://tirto.id/kompetisi-di-antara-berbagai-situsweb-islam-cEHi. 